\title{
Fossilized gut of the trilobite Lioparia bassleri and the distribution of exceptional preservation in the Cambrian Stage 4-Drumian Manto Formation of North China
}

\author{
Pingli Wang, Oldřich Fatka, Zhixin Sun, Petr Budil \& Jian Gao
}

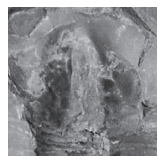

\begin{abstract}
The preservation of digestive structures of trilobites is not unique but recognition and reporting about these remains are rare. Here we describe a specimen of Lioparia bassleri Resser \& Endo, 1937, recently collected from the Weifang Biota in the Manto Formation (Cambrian, Miaolingian, Shandong, North China). This exceptionally preserved specimen displays the remains of the digestive system in the cephalon as well as in thoracic and pygidial parts of the body. The morphology of the remains of soft parts preserved in the specimen agrees with a simple digestive tract which included a simple gut tube in the thorax and pygidium associated with four pairs of cephalic gut diverticulae in the glabella. The morphology of the digestive tract of L. bassleri compares favourably with earlier observations on trilobites that had gut diverticulae. The preservation of the digestive system in the studied trilobite confirms that the depositional environment of the Manto Formation was favourable to soft-tissue preservation. Earlier papers on trilobites with preserved soft parts from China are summarized. Exceptional preservation of sponges, palaeoscolecids, radiodonts, bivalved arthropods, trilobites, and echinoderms in the Manto Formation is briefly discussed. $\cdot$ Key words: trilobites, digestive system, Weifang Biota, soft-tissue preservation, Manto Formation, mid-Cambrian, China.
\end{abstract}

Pingli Wang, Oldřich Fatka, Zhixin Sun, Petr Budil \& Jian Gao 2018. Fossilized gut of the trilobite Lioparia bassleri and the distribution of exceptional preservation in the Cambrian Stage 4-Drumian Manto Formation of North China. Bulletin of Geosciences 93(4), 491-498 (3 figures). Czech Geological Survey, Prague. ISSN 1214-1119. Manuscript received October 10, 2017; accepted in revised form November 2, 2018; published online November 29, 2018; issued December 20, 2018.

Pingli Wang, Shandong Provincial Key Laboratory of Depositional Mineralization \& Sedimentary Minerals, Shandong University of Science and Technology, Qingdao, Shandong 266590, China \& State Key Laboratory of Petroleum Resources and Prospecting, China University of Petroleum, Beijing 102249, China; wangpingli@126.com • Oldřich Fatka, Charles University, Faculty of Science, Institute of Geology and Palaeontology, Albertov 6, Praha 2, 128 43, Czech Republic $•$ Zhixin Sun, Shandong Provincial Key Laboratory of Depositional Mineralization \& Sedimentary Minerals, Shandong University of Science and Technology, Qingdao, Shandong 266590, China • Petr Budil, Czech Geological Survey, Klárov 3, Praha 1, 118 21, Czech Republic • Jian Gao, No. 136, West Xinhua Road, Lubei District, Tangshan 063000, China

Trilobites form an important part of the Palaeozoic fossil record, but knowledge about their non-mineralized parts, including the digestive system, is still very scanty. Babcock (2003), Lerosey-Aubril et al. (2011) and Robison $\&$ Babcock (2011) reviewed all earlier data on the gut of trilobites. Some 25 species having guts preserved were newly reported in Robison \& Babcock (2011). English $\&$ Babcock (2007) provided information on digestive tracts preserved in Ordovician trilobite material that was overlooked in previous years. Even with the addition of the paper of Lerosey-Aubril et al. (2011), not all species were reviewed, but in total, those papers account for, directly or by way of reference, about 50 species. Additional information on Cambrian species from Utah that have preserved guts was recently published also by Robison et al. (2015). However, the information on exceptionally preserved trilobites has increased in the last years due to intensive study of several Ordovician and particularly Cambrian Lagerstätten (e.g. Robison \& Babcock 2011; Lerosey-Aubril et al. 2011, 2012a, b, 2017; Eriksson \& Terfelt 2012; Fatka et al. 2013a, b, 2015; Zhu et al. 2014; Gutiérrez-Marco et al. 2017; Hopkins et al. 2017). Remains of the digestive system in Cambrian trilobites have been known from almost ten Konservat-Lagerstätten of four major areas - Laurentia, Baltica, West Gondwana and East Gondwana.

The aim of the present paper is to describe and illustrate an exceptionally preserved specimen of the trilobite Lioparia bassleri recently collected from the Manto Formation, North China (Sun \& Yuan, 2015). This spe- 


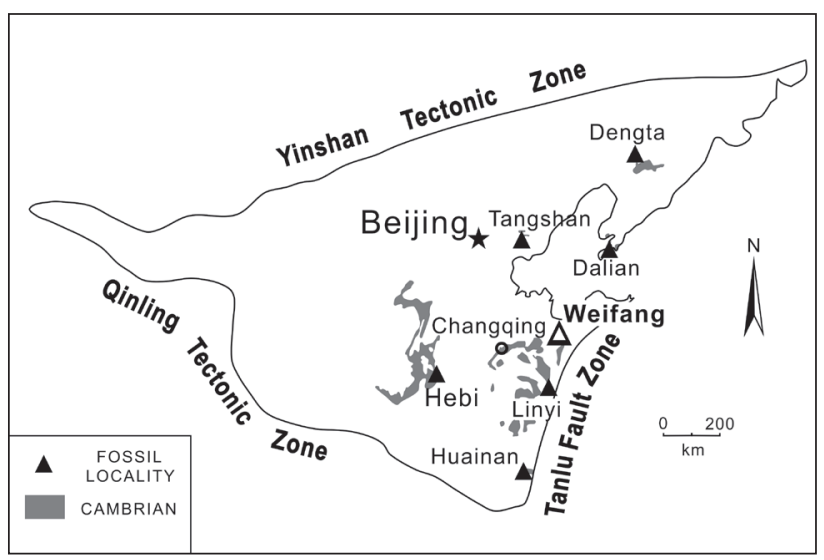

Figure 1. Distribution of Cambrian rocks within the North China Plate and geographic position of the western suburb of Weifang - the discovery site of Lioparia bassleri with digestive structures discussed in text.

cimen was mentioned in a preliminary abstract by Wang et al. (2014).

Trilobites with soft parts from China have been documented in more than ten contributions. Gut structures in Eoredlichia intermedia were studied by Shu et al. (1995) and Hou et al. (2009) from the Chengjiang Lagerstätte; these data were partially reinterpreted by Lerosey-Aubril et al. (2011). From this Konservat-Lagerstätte, a specimen of Kuanyangia (Sapushania) bella with incomplete anterior part of the alimentary structures was figured by Chen et al. (1996), Chen \& Zhou (1997) and Chen (2004); Zhang et al. (2003, text-fig. 7d) figured a juvenile naraoid similar to Primicaris larvaformis. Yuan et al. (2002) and Lin (2007) described gut structures in Olenoides paraptus from the Kaili Lagerstätte of Guizhou. From the same Lagerstätte, Zhao et al. (2005, pl. 3, fig. 4) figured a specimen of Oryctocephalus indicus with distinct remains of a gut canal preserved in the thorax and pygidium. Structures described by Lin (2007) were reinterpreted by Lerosey-Aubril et al. (2011). Specimens of Redlichia mai, Redlichia noetlingi and Palaeolenus lantenoisi with preserved remains of the gut from the Guangshan Lagerstätte were figured by $\mathrm{Hu}$ et al. (2013). More recently, Hopkins et al. (2017) studied the digestive system in several exceptionally preserved specimens of Palaeolenus lantenoisi and Redlichia mansuyi, all from the Guanshan Biota of Yunnan; a comprehensive list of Cambrian, Ordovician and Devonian trilobite taxa with part of digestive system was compiled in this contribution.

All these previously described examples are from South China (also see summary of early-middle Cambrian fossil Konservat-Lagerstätten in Zhang et al. 2008). In contrast, in North China, soft-bodied fossils have been sparsely reported, mostly from the Cambrian Manto Formation (Fig. 1), which has yielded the new specimen described herein.

\section{Geological setting and associated fossils}

The Manto Formation. - (Mantou Formation of some authors). The Manto Formation (Cambrian Series 2-Miaolingian) was named by Blackwelder (1907) from the stratotype section at Mantoushan, Zhangxia Town, Changqing County, Shandong Province (Fig. 1). Later the unit was subdivided into the Manto, Maochuang (= Maozhuang) and Hsuchuang (= Xuzhuang) formations (Lu \& Dong 1952) and this modified concept was accepted for decades. More recently, Zhang (1996) and Xiang et al. (1999) restored the original concept of Blackwelder (1907) to simplify this definition, which we follow in this contribution.

The Manto Formation is widely distributed, being identified in 11 provinces of North China (Xiang et al. 1999). This lithostratigraphic unit is characterized by purple, brownish-red or yellowish-green shales, with intercalated beds of limestone, dolostone or sandstone. It has been interpreted to represent a warm, arid tidal-flat and lagoonal facies (Xiang et al. 1999). The Manto Formation is transgressive, and its lower and upper boundaries are conspicuously diachronous.

In most places, for example in the interior and northeast areas of the North China Plate, the Manto Formation overlies the Changping Formation. The Zhushadong Formation underlies the Manto Formation at the southwestern plate margin. In some areas, the Manto Formation overlies the Huoshan Formation (near the southwest plate margin) or the Houjiashan Formation (south plate margin), or rests on the Precambrian (interior and northwestern plate areas). Lower levels of the Manto Formation are dominated by variegated shale or pelitic dolostone which contrasts with the limestone or dolostone that comprises underlying strata. The boundary between the Manto Formation and the overlying Changhia Formation can also be easily recognized by the siliciclastic rock below the boundary and the limestone above (Xiang et al. 1999).

Weifang Biota. - In the upper part of the Manto Formation, soft-bodied fossils were discovered by one of the authors (Zhixin Sun) in a western suburb of Weifang, Shandong, in 2009. A well-exposed, about 6-metres-thick sequence of calcareous purple-reddish shale, dark brown shale and yellowish-green shale intercalated with grey mediumto thick-bedded limestone is accessible at this outcrop. This assemblage of exceptionally preserved fossils was recently named the Weifang Biota by Sun \& Yuan (2015).

The Weifang Biota actually comprises two distinct assemblages. The lower assemblage belongs to the Bailiella-Lioparia Biozone and correlates with the upper part of Cambrian Stage 5 (the Wuliuan), according to Yuan et al. (2012). The upper assemblage, composed of most of the exceptionally preserved fossils yet found, occurs 
Figure 2. Stratigraphy of the Cambrian in North China with the stratigraphic position of the localities discussed in the text and the position of the Weifang Biota (stratigraphy modified from Peng 2009). As the Manto Formation is diachronous and there are still uncertainties about correlation between regional stages and global stages, the range of the Manto Formation, especially the upper boundary is tentative.

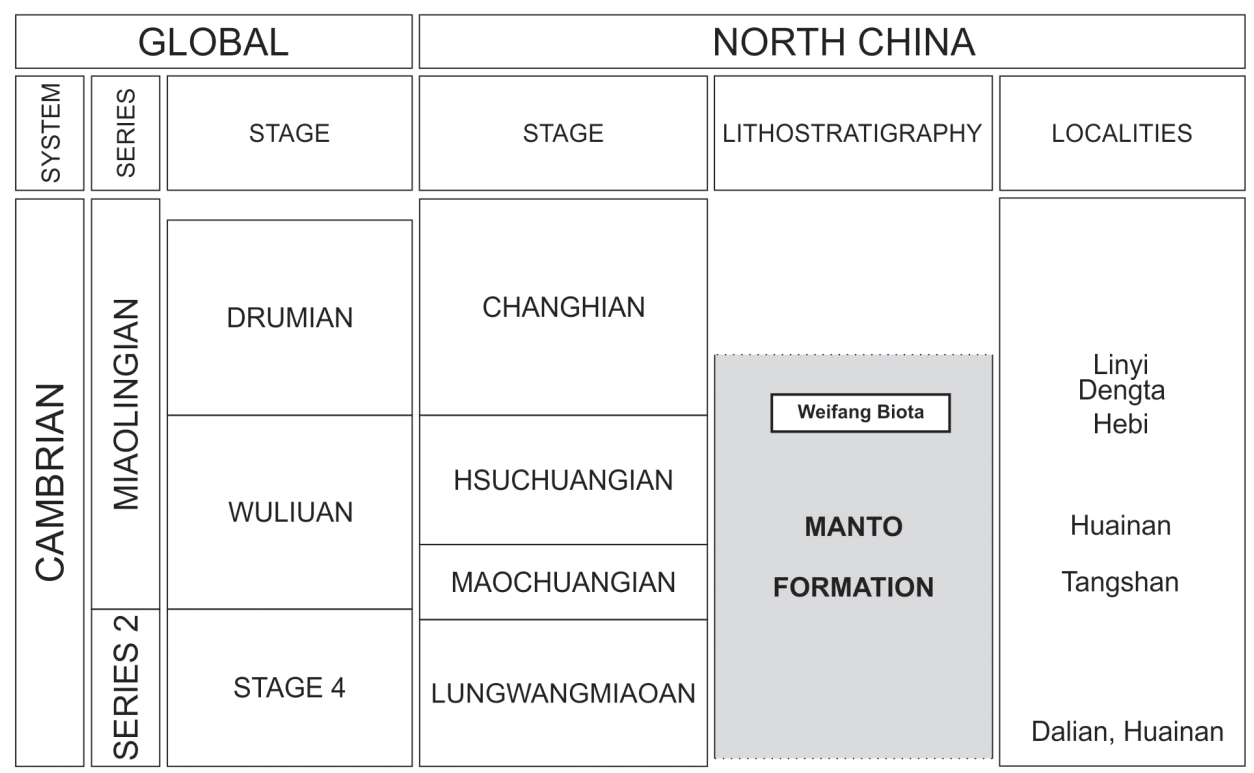

immediately above the Bailiella-Lioparia Biozone. Proasaphiscus yabei and Lioparia bassleri found in this upper assemblage are known to occur together with Ptychagnostus sinicus in the North China Plate (Wang et al. 1954, Lu 1957, Guo et al. 1996, Yuan et al. 2012). Ptychagnostus sinicus was considered by Sun (1989) and Peng (2009) to be synonymous with the index agnostid species Ptychagnostus intermedius, which occurs in the Triplagnostus (or Ptychagnostus) gibbus to Acidusus (or Ptychagnostus) atavus biozones (Robison 1982, 1984). Accordingly, the upper assemblage of the Weifang Biota is most probably of early Drumian age (Fig. 2).

Preliminary analysis of the material collected so far documents a mixture in the Weifang Biota of biomineralized and non-biomineralized animals along with algae. Abundant articulated trilobites of the species Bailiella sp., ?Eosoptychoparia hoboi (= Elrathia hoboi), Honanaspis honanensis, Lioparia bassleri, Proasaphiscus yabei and Psilaspis changchengensis are associated with the large bivalved arthropod Tuzoia manchuriensis (see Sun et al. 2015). The associated fauna includes a threedimensionally preserved hyolith conch with operculum and helens, another hyolith conch with possible remains of gut structures, as well as brachiopods and problematic fossils. Internal and external moulds of one trilobite specimen are preserved with possible digestive structures.

\section{Results}

\section{Description}

Partially damaged internal and external moulds of a complete articulated exoskeleton of Lioparia bassleri are preserved in yellowish-green shale. The original calcareous cuticle of the exoskeleton was lost during diagenesis; both internal and external moulds are composed of the rock matrix (clay minerals) with iron oxides. The specimen is about $32 \mathrm{~mm}$ long (sag.), $21 \mathrm{~mm}$ in width (tr) and oriented parallel to the bedding. The exoskeleton has eleven thoracic segments, suggesting a holaspid growth stage. All parts of the dorsal exoskeleton are intact, the hypostome is not visible, the rostral plate is exposed in front of the glabella (RP in Fig. 3B), and the cephalic shield is slightly warped and cracked.

The internal mould of the cephalon has both left and right librigenae only partly preserved. The anterior and lateral cephalic parts are broken off in the external mould. Except for four anterior thoracic segments, all other thoracic pleurae are broken off distally on the left side of the internal mould. On the external mould, the axis is very slightly damaged by an oblique fracture, and the left side of the axial and proximal parts of the third to eleventh segments are peeled off.

The left postero-lateral part of the pygidium is missing on the internal mould (Fig. 3A). The external mould of the pygidium is undamaged but part of the doublure is embedded in the matrix. A tiny Gordia-type ichnofossil is preserved near the right postero-lateral margin of the pygidium (Fig. 3B).

The specimen exhibits brown to black markings under the axial lobe of the cephalon, thorax and pygidium (Fig. 3), which are interpreted as remains of the gut. A large polylobate dark marking occurs under the slightly vaulted glabella (GL in Fig. 3B) and the adaxial part of the right fixigena (Fig. 3A, C). A longitudinal dark marking of variable width is visible on the external and internal moulds along the axis of all thoracic segments 
( $\mathrm{G}$ in Fig. 3B, E). On the internal mould, the darker area reaches nearly fifty percent of the axial width in the five anteriormost thoracic segments, as well as in the anterior part of the pygidium. A slightly narrower marking is seen in the more completely preserved external mould of the pygidium; this marking gently narrows posteriorly. It is not apparent whether this marking reaches the posterior tip of the pygidial axis (Fig. 3F). There are no distinctive sedimentary particles visible within the dark marking.

\section{Interpretation}

We interpret the above described dark marking preserved under the axis of this specimen as remains of a relatively simple digestive tract. Four pairs of distinct lobes developed in the cephalon are regarded as evidence of four pairs of cephalic diverticulae (Dc1 to Dc4 in Fig. 3B). The anteriormost four or five thoracic segments might also preserve diverticulae, but the outline of the dark marking is not clear there. Posteriorly, the gut might be restricted to a simple tube devoid of diverticulae ( $G$ in Fig. 3B, E).

The slightly asymmetrical position of the assumed digestive tract presumably resulted from a post-mortem deformation of soft parts with respect to the dorsal exoskeleton. During this deformation, the alimentary canal and the other attached organs would have been shifted from their sagittal position.

Ichnofossils associated with exceptionally preserved fossils have been reported from several Cambrian Konservat-Lagerstätten (Babcock \& Peel 2007, Wang et al. 2009, Lin et al. 2010, Mángano 2011, Mikuláš et al. 2012). The occurrence of a Gordia-type ichnofossil in the studied specimen of $L$. bassleri indicates an oxygenated sea bottom (see Lin et al. 2010, p. 253).

\section{Discussion - Exceptional preservation in the Manto Formation}

The Manto Formation has recently yielded bivalved arthropods, palaeoscolecids, articulated echinoderms and sponges, anomalocaridids and trilobites with soft parts, which attests to the presence of exceptional preservation in the Cambrian of North China. So far, most studies have been undertaken by Diying Huang (Nanjing Institute of Geology and Palaeontology, Chinese Academy of Sciences) and his team, who have emphasized a great potential for more exceptionally preserved specimens to be discovered in the Manto Formation.

Bivalved arthropods. - Resser (1929) reported the occurrence of a non-mineralized arthropod Tuzoia at Dengta (Figs 1, 2), Liaoning Province, northern margin of the North China Plate. It is associated with the trilobites Proasaphiscus yabei, Lioparia bassleri and Lioparia walcotti, a lingulid brachiopod Lingulella tangshihensis, and a hyolithid Hyolithes carinferus. More recently, Sun et al. (2015) described Tuzoia manchuriensis from the same locality as the specimen of Lioparia bassleri with digestive structures described herein.

Wang et al. (2010) described a new species of Isoxys, I. shandongensis, from the upper part of the Manto Formation at Linyi, Shandong Province (Figs 1,2). This locality also yielded abundant articulated trilobites (mainly Maotunia), sponges, chancelloriids, hyoliths, brachiopods and non-trilobite arthropods. In North China, Maotunia is considered to occur in the Changhian Regional Stage (Yuan et al. 2012), and the fauna at Linyi is considered to be of Drumian Age (Fig. 2).

Palaeoscolecids. - Lin (1995) established a new species of these stem-priapulid worms, Palaeoscolex huainanensis, collected from a purple shale in the lower part of the Manto Formation, Huainan, Anhui Province, southern margin of the North China Plate (Figs 1,2). This species coexisted with Redlichia (Pteroredlichia) chinensis, Redlichia triangularis and Leptoredlichia tumidolimbata. Hence, the rock unit can be correlated to Cambrian Stage 4 (Peng 2009).

Echinoderms. - Huang (2012) discussed more than two hundred specimens of an unnamed eocrinoid from the amaranthine calcareous mudstone at Dalian, Liaoning Province (Figs 1,2). They are associated with abundant trilobite fragments of Redlichia murakamii and with brachiopods. Eocrinoids have been widely reported from the Yangtze Platform in Yunnan and Guizhou provinces, but are usually rare in North China. The eocrinoid-bearing level belongs to the Redlichia (Pteroredlichia) chinensis Zone (Huang 2012), and therefore can be assigned to Cambrian Stage 4 (Peng 2009).

Anomalocaridids. - Huang et al. (2012) reported the discovery of an anomalocaridid frontal appendage from the purple-reddish shale of the Manto Formation at Tangshan, Hebei Province (Figs 1, 2). According to Huang et al. (2012), co-occurring trilobites, hyoliths and brachiopods indicate the Luaspides huoshanensis Zone corresponding to the Wuliuan Stage of the Miaolingian Series. Anomalocaridids are quite common in Cambrian faunas in South China, such as the Chengjiang, Niutitang, Guanshan and Kaili faunas, but are rare in North China.

Sponges. - Liu et al. (2012) described the articulated sponges Diagoniella pera and a possible Protospongia from the top of the Manto Formation, near Hebi, Henan 

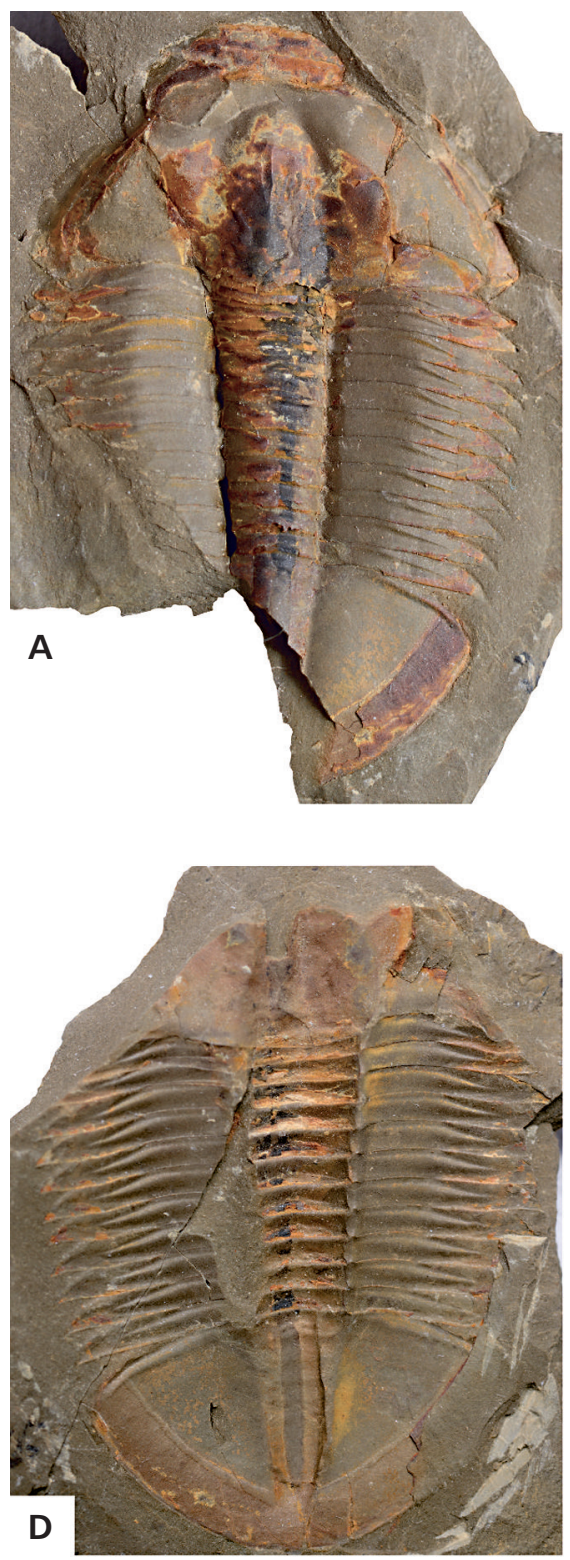

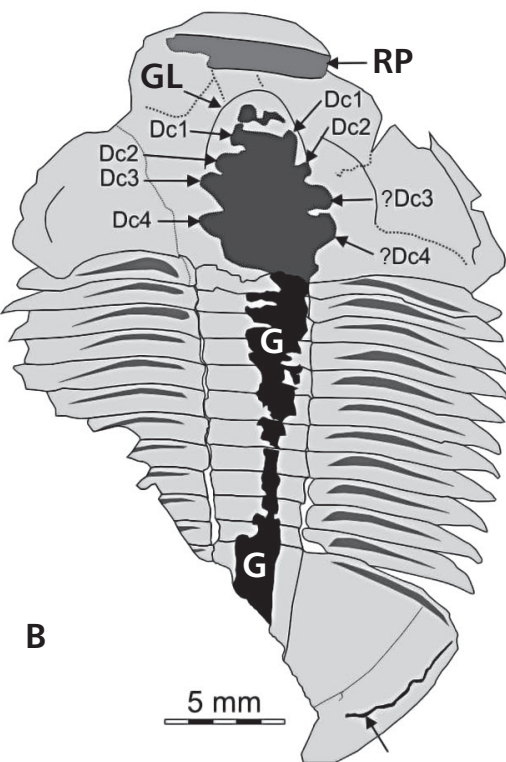

Gordia-type ichnofossil
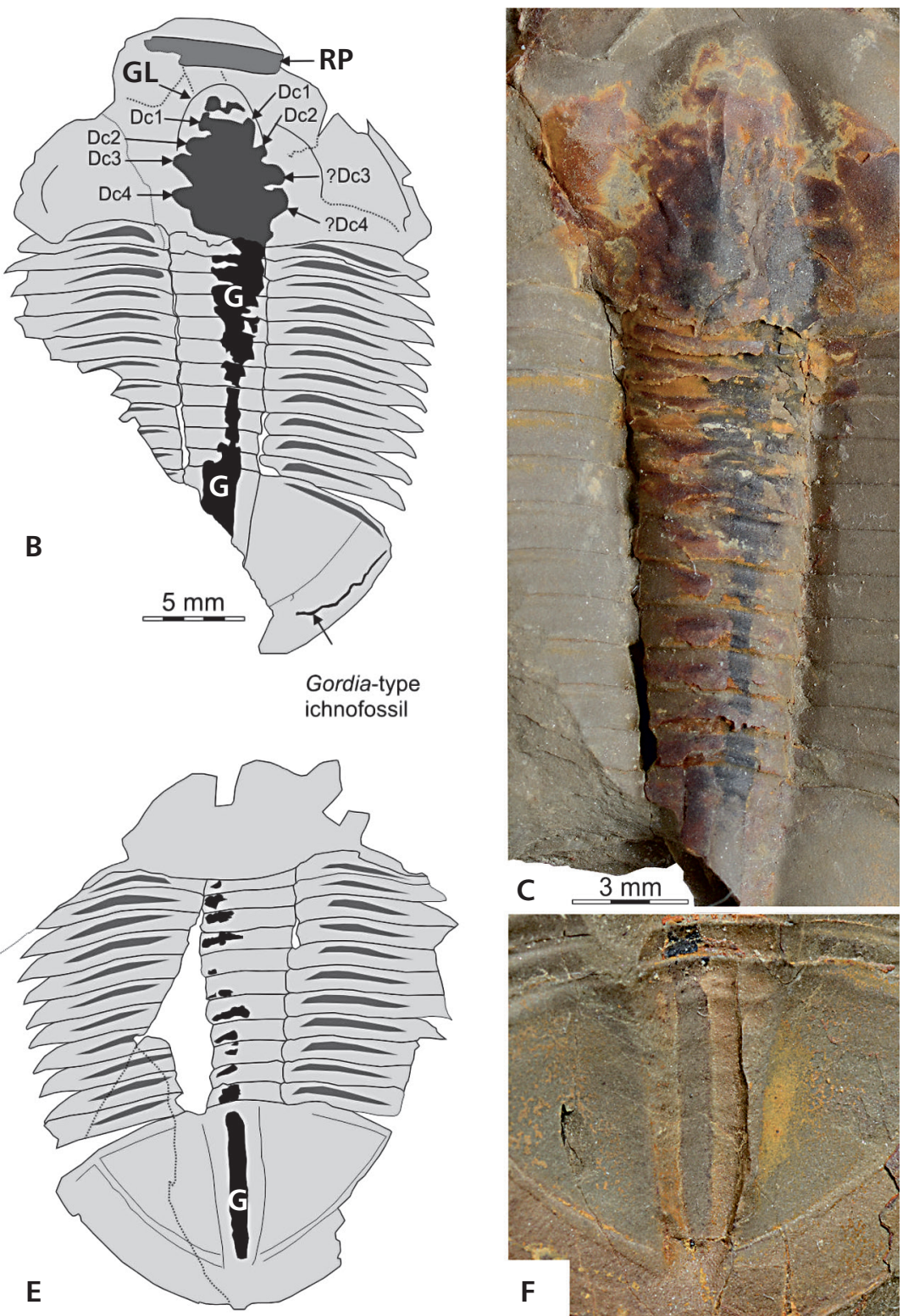

Figure 3. Lioparia bassleri Resser \& Endo, 1937 with remains of the digestive system, middle Cambrian Manto Formation (Cambrian, Drumian Stage, Weifang Biota, Shandong, North China). Housed at the Shandong University of Science and Technology, under the number WF-WDS-0001a, b. A - internal mould with assumed remains of digestive system; B - interpretative sketch; C - axial part of internal mould; D - external mould with remains of digestive system; E - interpretative sketch; F - axial part of external mould. Abbreviations: Dc - pairs of cephalic gut diverticulae; $\mathrm{G}$ - gut; GL - glabella; RP - rostral plate.

Province (Figs 1,2). This was the first report of articulated sponges in North China. This locality also yields Bailiella, Lioparia, Tuzoia, hyoliths, chancelloriids and brachiopods. The Bailiella-Lioparia Zone is considered to be timeequivalent to the Wuliuan Stage of the Miaolingian Series (Peng 2009).

Trilobites with soft-parts. - An enrolled trilobite specimen with a partly preserved gut was tentatively assigned to Jiumenia anhuiensis by Zhu et al. (2014). It is associated with Huaiaspis huainanensis and Zhongtiaoshanaspis huainanensis. The exceptionally preserved specimen was collected in red shales with interbedded siltstones in the upper part of the Manto Formation (Miaolingian Series, Wuliuan Stage, Huainan, Anhui Province; Figs 1, 2). However, it comes from a different outcrop than the above mentioned palaeoscolecid. The three-dimensional preservation of the gut in this specimen was attributed to rapid burial, resulting in the physical protection of these delicate remains. 


\section{Conclusions}

(1) The dark markings in the axial parts of the cephalon, thorax and pygidium observed in the exceptionally preserved specimen of Lioparia bassleri are interpreted as remains of a simple digestive tract composed of four pairs of cephalic gut diverticulae associated with a supposedly simple gut tube in the thorax and pygidium. Such morphology of the digestive tract agrees with the observation of Lerosey-Aubril et al. (2011, p. 180), who suggested that differentiation of a crop in trilobites was probably the result of secondary evolution.

(2) The occurrence of a Gordia-type ichnofossil in the studied specimen of $L$. bassleri indicates an oxygenated sea bottom at the time of burial.

\section{Acknowledgements}

We thank Jinliang Yuan (Nanjing Institute of Geology and Palaeontology, Chinese Academy of Sciences) for valuable suggestions on fieldwork and for constructive reviews on parts of the manuscript; Zhikun Gai and Yemao Hou (Institute of Vertebrate Paleontology and Paleoanthropology, Chinese Academy of Sciences) for technical support; and Per Ahlberg (Lund University) for sending helpful literature. The authors thank Rudy Lerosey-Aubril (University of New England, Armidale, Australia) and an anonymous reviewer for their comments, which greatly helped to improve the manuscript. Research of Pingli Wang, Zhixin Sun and Jian Gao was supported by the National Natural Science Foundation of China (41402011), the Shandong Provincial Natural Science Foundation, China (ZR2013DQ019), the Foundation of State Key Laboratory of Petroleum Resources and Prospecting, China University of Petroleum, Beijing (PRP/open-1406), and the Foundation of Shandong Provincial Key Laboratory of Depositional Mineralization \& Sedimentary Minerals (DMSM201402); that of O. Fatka by PROGRES Q45 of the Ministry of Education, Youth and Sports of Czech Republic and the Czech Geological Survey internal project No 339900. This research was supported by the Czech Science Foundation (GACR) project no. 18-14575S (OF and PB). This work is a contribution to the IGCP Project 653 'The Onset of the Great Ordovician Biodiversification Event'.

\section{References}

BABCOCK, L.E. 2003. Trilobites in Paleozoic predator-prey systems, and their role in reorganization of early Paleozoic ecosystems, 55-92. In Kelley, P.A., Kowalewski, M. \& Hansen, T.A. (eds) Predator-prey interactions in the fossil record. Kluwer Academic/Plenum Publishers, New York.

BABCock, L.E. \& Peel, J.S. 2007. Palaeobiology, taphonomy and stratigraphic significance of the trilobite Buenellus from the
Sirius Passet Biota, Cambrian of North Greenland. Memoirs of the Association of Australasian Palaeontologists 34, 401-418.

BlackWelder, E. 1907. Stratigraphy of Shantung, 19-58. In Willis, B., Blackwelder, E. \& Sargent, R.H. (eds) Research in China. Vol. 1, Pt. 1. Descriptive topography and geology. Section 1, northeastern China. Carnegie Institution of Washington, 54(1).

Chen, J.Y. 2004. The dawn of animal world. 366 pp. Jiangshu Publishing House of Science and Technology, Nanjing. [in Chinese]

Chen, J.Y. \& Zhou, G.Q. 1997. Biology of the Chengjiang fauna. Bulletin of the National Museum of Natural Science 10, 11-106.

Chen, J.Y., Zhou, G.Q., Zhu, M.Y. \& Yen, K.Y. 1996. Chengjiang Biota - A unique window of the Cambrian explosion. 222 pp. National Museum of Natural Science, Taichung, Taiwan.

English, A.M. \& BABCOCK, L.E. 2007. Feeding behaviour of two Ordovician trilobites inferred from trace fossils and nonbiomineralised anatomy, Ohio and Kentucky, USA. Memoirs of the Association of Australasian Palaeontologists 34, 537-544.

Eriksson, M.E. \& Terfelt, F. 2012. Exceptionally preserved Cambrian trilobite digestive System Revealed in 3D by synchrotron-radiation X-ray tomographic microscopy. PLoS ONE 7(4), e35625. DOI 10.1371/journal.pone.0035625

FatKa, O., Budil, P. \& David, M. 2015. Digestive structures in Ordovician trilobites Colpocoryphe and Flexicalymene from the Barrandian area of Czech Republic. Estonian Journal of Earth Sciences 64(4), 255-266.

DOI 10.3176/earth.2015.32

Fatka, O., Mergl, M. \& Budil, P. 2013b. Preservation of the digestive structures in Harpides (Trilobita) from the Lower Ordovician of the Barrandian area (Czech Republic). Neues Jahrbuch für Geologie und Paläontologie Abhandlungen 270(1), 55-67. DOI 10.1127/0077-7749/2013/0357

Fatka, O., Lerosey-Aubril, R., Budil, P. \& Rak, Š. 2013 a. Fossilised guts from the Upper Ordovician Letná Formation (Prague Basin, Czech Republic). Bulletin of Geosciences 88(1), 95-104. DOI 10/3140/bull.geosci.1329

Guo, H., ZAN, S. \& Luo, K. 1996. Cambrian stratigraphy and trilobites of eastern Liaoning. 184 pp. Jilin University Press, Changchun. [in Chinese with English abstract]

Gutiérrez-Marco, J.C., García-Bellido, D.C., Rábano, I. \& SÁ, A.A. 2017 Digestive and appendicular soft-parts, with behavioural implications, in a large Ordovician trilobite from the Fezouata Lagerstätte, Morocco. Scientific Reports 7(39728). DOI 10.1038/srep39728

Hopkins, M.J., Chen, F., Hu, S. \& Zhang, Z. 2017. The oldest known digestive system consisting of both paired digestive glands and a crop from exceptionally preserved trilobites of the Guanshan Biota (early Cambrian, China). PLoS ONE 12(9), e0184982. DOI 10.1371/journal.pone.0184982

Hou, X.G., Clarkson, E.N.K., Yang, J., Zhang, X.G., Wu, G.Q. \& YuAn, Z. 2009. Appendages of early Cambrian Eoredlichia (Trilobita) from the Chengjiang biota, Yunnan, China. Earth 
and Environmental Science Transactions of the Royal Society of Edinburgh 99(3-4), 213-223.

DOI $10.1017 / \mathrm{S} 1755691009008093$

Hu, S.X., Zhu, M.Y., Luo, H.L., Steiner, M., Zhao, F.C., Li, G.X. \& Zhang, Z.F. 2013. The Guangshan Biota. 204 pp. Yunnan Science and Technology Press. Kunming.

Huang, D.Y. 2012. Eocrinoids from the Cambrian Mantou Formation of Dalian, Liaoning. Chinese Science Bulletin 57(30), 3855-3857. DOI 10.1007/s11434-012-5433-3

Huang, D.Y., Wang, Y.Y., GaO, J. \& Wang, Y.A. 2012. A new anomalocaridid frontal appendage from the middle Cambrian Mantou Formation of the Tangshan area, Hebei. Acta Palaeontologica Sinica 51(4), 411-415.

Lerosey-Aubril, R., Hegna, T.A. \& Olive, S. 2011. Inferring internal anatomy from the trilobite exoskeleton: the relationship between frontal auxiliary impressions and the digestive system. Lethaia 44(2), 166-184.

DOI 10.1111/j.1502-3931.2010.00233.x

Lerosey-Aubril, R., Hegna, T.A., Kier, C., Bonino, E., Habersetzer, J. \& Carré, M. 2012a. Exploring the preservation of digestive structures of fossil arthropods: The phosphatisation of trilobite guts in the Weeks Formation Lagerstätte (Cambrian; Utah), 171-172. In ZHAO, Y.L., Zhu, M.Y., Peng, J., Gaines, R.R. \& Parsley, R.L. (eds) Cryogenian-Ediacaran to Cambrian stratigraphy and paleontology of Guizhou, China. Journal of Guizhou University, Natural Science 29(Sup. 1).

Lerosey-Aubril, R., Hegna, T.A., Kier, C., Bonino, E., Habersetzer, J. \& Carré, M. 2012b. Controls on gut phosphatisation: the trilobites from the Weeks Formation Lagerstätte (Cambrian; Utah). PLoS ONE 7(3), e32934.

DOI 10.1371/journal.pone.0032934

Lerosey-Aubril, R., Paterson, J.R., Gibb, S. \& Chatterton, B.D.E. 2017. Exceptionally-preserved late Cambrian fossils from the McKay Group (British Columbia, Canada) and the evolution of tagmosis in aglaspidid arthropods. Gondwana Research 42, 264-279. DOI 10.1016/j.gr.2016.10.013

Lin, J.P. 2007. Preservation of the gastrointestinal system in Olenoides (Trilobita) from the Kaili Biota (Cambrian) of Guizhou, China. Memoirs of the Association of Australasian Palaeontologists 33, 179-189.

Lin, J.P., Zhao, Y.L., Rahman, I.A., Xiao, S. \& Wang, S. 2010. Bioturbation in Burgess Shale-type Lagerstätten - case study of trace fossil-body fossil association from the Kaili Biota (Cambrian Series 3), Guizhou, China. Palaeogeography, Palaeoclimatology, Palaeoecology 292(1-2), 245-256.

DOI 10.1016/j.palaeo.2010.03.048

Lin, T. 1995. Discovery of late early Cambrian worm from Huainan, Anhui. Acta Palaeontologica Sinica 34(4), 505-508. [in Chinese with English abstract]

Liu, Q., Huang, D. \& Gong, Y. 2012. Sponge fossils from the Cambrian Mantou Formation of Hebi, Henan, Central China. Journal of China University of Geosciences 37(Sup. 2), 129135. [in Chinese with English abstract]

DOI 10.3799/dqkx.2012.S2.013

Lu, Y. 1957. Trilobites, 249-294. In Gu, Z., YANG, Z., Xu, J., Yin, Z., Yu, J., Zhao, J., Lu, Y. \& Hou, Y. (eds) Index fossils of China. Invertebrates, Part 3. Geological Publishing House, Beijing. [in Chinese]

Lu, Y. \& Dong, N. 1952. Revision of the Cambrian type sections of Shandong. Acta Geologica Sinica 32(3), 1-23. [in Chinese]

Mángano, M.G. 2011. Trace-fossil assemblages in a Burgess Shale-type deposit from the Stephen Formation at Stanley Glacier, Canadian Rocky Mountains: Unravelling ecologic and evolutionary controls, 89-107. In Johnston, P.A. \& Johnston, K.J. (eds) Proceedings of the International Conference on the Cambrian Explosion. Palaeontographica Canadiana 31.

Mikuláš, R., Fatka, O. \& Szabad, M. 2012. Paleoecologic implications of ichnofossils associated with slightly skeletonized body fossils, middle Cambrian of the Barrandian area, Czech Republic. Ichnos 19(4), 199-210. DOI 10.1080/10420940.2012.703626

PENG, S. 2009. Review on the studies of Cambrian trilobite faunas from Jiangnan Slope Belt, South China, with notes on Cambrian correlation between South and North China. Acta Palaeontologica Sinica 48(3), 437-452. [in Chinese with English abstract]

Resser, C.E. 1929. New Lower and Middle Cambrian Crustacea. Proceedings of the United States National Museum 76(9), 1-18. DOI 10.5479/si.00963801.76-2806.1

Resser, C.E. \& Endo, R. 1937. Description of the fossils, 103-301. In Endo, R. \& Resser, C.E. (eds) The Sinian and Cambrian formations and fossils of southern Manchoukuo. Manchurian Science Museum Bulletin 1.

Robison, R.A. 1982. Some Middle Cambrian agnostoid trilobites from western north America. Journal of Paleontology 56(1), 132-160.

Robison, R.A. 1984. Cambrian Agnostida of North America and Greenland. Part I, Ptychagnostidae. University of Kansas Paleontological Contributions, Paper 109, 1-59.

Robison, R.A. \& BABCOCK, L.E. 2011. Systematics, paleobiology, and taphonomy of some exceptionally preserved trilobites from Cambrian Lagerstätten of Utah. Kansas University Paleontological Contributions 5, 1-47.

Robison, R.A., Babcock, L.E. \& Gunther, V.G. 2015. Exceptional Cambrian fossils from Utah: a window into the Age of Trilobites. Utah Geological Survey, Miscellaneous Publication 15, 1-97.

Shu, D.G., Geyer, G., Chen, L. \& Zhang, X.L. 1995. Redlichiacean trilobites with preserved soft-parts from the Lower Cambrian Chengjiang fauna (South China). Beringeria, Special Issue 2, 203-241.

Sun, X. 1989. Cambrian agnostids from the North China platform. Palaeontologia Cathayana 4, 53-129.

Sun, Z.X. \& Yuan, J.L. 2015. The Weifang Biota from Cambrian Series 3, North China. The 28 th Annual Conference of Palaeontological Society of China. Abstract Volume, 40-41. [in Chinese]

Sun, Z.X., Wang, P.L. \& Yuan, J.L. 2015. The first complete Tuzoia manchuriensis from the Cambrian Series 3 of Weifang, Shandong Province. Acta Palaeontologica Sinica 54(1), 113-119. [in Chinese with English abstract] 
Wang, P.L., Sun, Z.X. \& Yuan, J.L. 2014. Preliminary study on an exceptionally well preserved fauna from the Mantou Formation, Cambrian Series 3, Weifang City Shandong, 185-188. In Zhan, R.B. \& HuAng, B. (eds) IGCP 591 Field Workshop 2014, Kunming China, 12-21 August 2014, Extended Summary. Nanjing University Press, Nanjing.

Wang, Y., Huang, D. \& Lieberman, B.S. 2010. New Isoxys (Arthropoda) from the Mantou Formation, Shandong Province. Acta Palaeontologica Sinica 49(3), 398-406. [in Chinese with English abstract]

WANG, Y., Lin, J.P., ZhaO, Y.L. \& ORR, P.J. 2009. Palaeoecology of the trace fossil Gordia and its interaction with nonmineralizing taxa from the early Middle Cambrian Kaili Biota, Guizhou Province, South China. Palaeogeography, Palaeoclimatology, Palaeoecology 177(1-2), 141-148. DOI 10.1016/j.palaeo.2009.02.017

WANG, Y., Lu, Y., YANG, J., Mu, E. \& ShEng, J. 1954. Stratigraphy of Taizi River Valley in Liaoning, 1. Acta Geologica 34(1), 17-64. [in Chinese]

Xiang, L.W., Zhu, Z.L., Li, S.J. \& Zhou, Z.Q. 1999. Chinese stratigraphic lexicon (The Cambrian). 95 pp. Geological Publishing House, Beijing.

Yuan, J., Li, Y., Mu, X., Lin, J.P. \& Zhu, X. 2012. Trilobite fauna of the Changhia Formation (Cambrian Series 3) from Shandong and adjacent area. Palaeontologica Sinica, New Series B 35, 1-758. [in Chinese with English summary]
Yuan, J.L., Zhao, Y.L., Li, Y. \& Huang, Y.Z. 2002. Trilobite Fauna of the Kaili Formation (uppermost Lower Cambrianlower Middle Cambrian) from southeastern Guizhou, South China. 423 pp. Shanghai Science and Technology Press, Shanghai.

Zhang, X., Liu, W. \& Zhao, I. 2008. Cambrian Burgess Shale-type Lagerstätten in South China: Distribution and significance. Gondwana Research 14(1-2), 255-262. DOI 10.1016/j.gr.2007.06.008

Zhang, X., Han, J., Zhang, Z., Liu, H. \& Shu, D. 2003. Reconsideration of the supposed naraoiid larva from the Early Cambrian Chengjiang Lagerstätte, South China. Palaeontology 46(3), 447-465. DOI 10.1111/1475-4983.00307

Zhang, Z. 1996. Cambrian-Ordovician, 43-44. In Zhang, Z. \& Liu, W. (eds) Lithostratigraphy of Shandong Province. China University of Geosciences Press, Wuhan. [in Chinese]

Zhao, Y., Zhu, M., Babcock, L.E., Yuan, J., Parsley, R.L., Peng, J., YAng, X. \& Wang, Y. 2005. Kaili Biota: a taphonomic window on diversification of metazoans from the basal Middle Cambrian: Guizhou, China. Acta Geologica Sinica 79(6), 751-765. DOI 10.1111/j.1755-6724.2005.tb00928.x

Zhu, X.J., Lerosey-Aubril, R. \& Esteve, J. 2014. Gut content fossilization and evidence for detritus feeding habits in an enrolled trilobite from the Cambrian of China. Lethaia 47(1), 66-76. DOI 10.1111/let.12041 